\title{
(RE)-INTERPRETATION OF THE PAER SPACE CONCEPT AN ENVIRONMENTAL PATTERN APPROACH THROUGH A MULTILEVEL
}

Received December 1 ${ }^{\text {st }}, 2020$ | Accepted July 9th, 2021 | Available online December 15th, 2021 | DOI http://dx. doi. org/10.18860/jia.v6i4.10910

Taufan Hidjaz Ovan

Institur Teknologi Nasional

Bandung, Indonesia

taufanhidjaz@yahoo.co.id

\begin{abstract}
Lombok is called the Island of Thousand Mosques. Its inhabitants from the Sasak ethnic group are Muslim, who have the concept of the Paer space. It is a place of the existential transience of life, and the center is a mosque. The Paer space is implemented to have a hierarchy from a family cluster environment called paer bale langgak, paer dusun, paer village, and paer cardinal area, which function as the places for worship and culture to spend their remaining time towards an eternal time in the afterlife. This study identifies how religious, social, and cultural activities in the Paer space are centered on the mosque's architecture and interprets the patterns of the community behavior that influence each other in it. The concept of Paer or temporary existential space is then reinterpreted using descriptive-analytical -qualitative methods to obtain a schematic environmental pattern that can be developed adaptively in Muslim communities with mosque as the center of orientation for worship and cultural activities.
\end{abstract}

KEYWORDS:

paer space; reinterpretation; environment; mosque architecture

\section{INTRODUCTION}

Paer Space is the concept of a residential environment for the Sasak people on the island of Lombok based on Islamic beliefs; it's about existential life in this world, which is temporary, before an eternal life after death [1]. Human life, based on the Islamic concept, containing intentional behavior directed towards eternal life in the hereafter is the most important thing for the Sasak people. The term Paer in the Kawi-Javanese dictionary written by CF Winter $\mathrm{Sr}$ and R. Ngabehi Ranggawarsita is related to two words, namely pahera pangentosan, which means waiting, and pahyaran panggenan, which means a place to stay. So, Paer is a place to stay during their remaining time [2]. Paer is a place of humans' existential life and is a temporary space as defined in Edmund Husserl's Phenomenology - live one's daily life that surround and shape one's reality in society, namely the elements of cultural space that one experiences before death. The Paer concept always requires a spatial orientation in the form of a place as the center of all activities to fill a period of the existential waiting (before death). Ineun Paer, the center of the waiting space, is an adaptation of Ineun tetaog or the center of space during the Sasak Lebung period before the Islam period, which was associated with important natural objects in the residential environment such as springs or large trees [3]. The Islam development was then marked by the influence of the transformation of the mosque, from the traditional house (4).

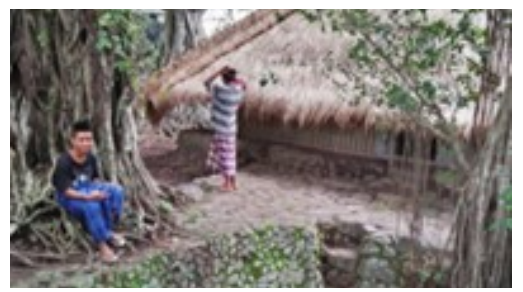

Figure 1. Springs and large trees are the orientation of the place during the Sasak Lebung period.

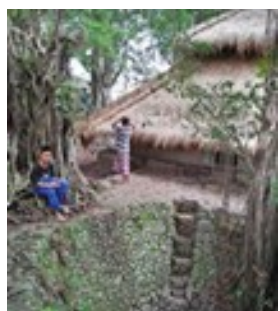

(a)

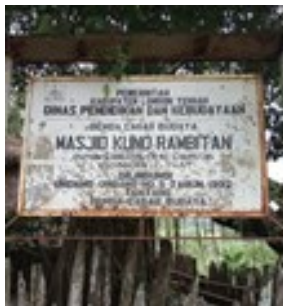

(b)
Figure 2 (a) An ancient mosque in Rambitan village was later built next to a spring. The beginning of the transformation of the old Sasak community was initially oriented to natural objects as the orientation places or Ineun Tetaoq, which are then adapted with a mosque building with a simple building. (b) The signboard for the status of the ancient Rembitan mosque is important because it points to the early traces of the arrival of Islam in Lombok from the North (Paer daye)

After converting to Islam due to Javanese and Sulawesi immigrants, the Sasak people have built 
mosques beyond the area of origin of the bearers. Still, there has been no research refers the mosque building as a center for the orientation of the Paer Space, as a continuation of the concept of Ineun Tetaoq's space orientation in the pre-Islamic period. The previous research on Paer space was only related to the cosmology of tiered spatial levels and cardinal directions. Later, this study found out that the realization of the need for Paer space for this orientation center encouraged 536 villages throughout Lombok to build mosques has required 9,008 artifacts [5]. Paer hamlet and paer desa environments place the environmental center artifacts in a spatial structure representing Sasak culture. The cultural space in Lombok is a natural space where Sasak culture takes place, forming a patterned level of relationship with the center of activity in the mosque. The formation of a structural pattern of spatial relations when carrying out various activities in Islam is more important when it is carried out collectively in the mosque. This adaptation places the mosque in the most important position as a residential center for the community in Lombok. Mosques are among the most important building types for any Muslim community; it is a gathering place for doing prayers and social activities [6]. However, the mosque in the Sasak residential area with the Paer Space concept does not only reflect the functional building of a place of worship but also the realization of the people's perspective on the temporary life of the world and the eternal life in the hereafter. Therefore, apart from the physical nature, the mosque for the Sasak residential environment has spiritual value and becomes a concrete picture of Sasak culture.

Through a qualitative-analytical description, this research identifies the activities performed in the Paer space with an approach to the mosque as the center, then interprets the patterns of community behavior that influence each other in relation to the mosque and the Paer space. The purpose of the research is to acquire the meaning that will be interpreted from the relationship of the patterned activities and the Paer space as an aspect of local wisdom of the Sasak community. It is going to be developed adaptively in each pattern of residential environments with mosque architecture as the center of orientation. The indirect benefit is the development of human welfare as a subject, and its success can be felt physically and spiritually. The significance of this research is to understand how the Muslim community's environmental development program should make mosque architecture as the basis for synergizing the goals of happiness in the world only temporarily but happiness in afterlife is eternal. The architecture reflects the community's identity from the character features resulted from cultural patterns: symbols, social events, economics, politics, ideological and historical features, traditions, customs, and community values [7]. Architecture is an expression of culture; its manifestations tells us something about ourselves, our aspirations, and our desires although none of these have ever been direct (8).

The transformation of the residential space of the Sasak people from the beginning was oriented towards natural objects (mountains, springs, big trees). After converted to Islam, they shifted their orientation to mosques. The mosque architecture was built in a monumental position, surrounded by simple hamlet residential clusters, and it was not attached to the main road. It indicates that the residential pattern in Lombok village considers the position around the mosque than around the transportation route for economic activities. This residential pattern of rural environmental culture is interesting as an illustration of the ability of the villages to provide food that support the needs of urban communities. It also shows historical integration in its socio-economic potential that can develop relations between rural areas. This strengthening occupancy patterns could be a useful implication of the study results as most of the population live in villages, where almost half of the human population live in. It constitutes ninety-seven percent of the world's landmass defined as "nonurban" [9].

\section{METHODS}

Through the concept of the Paer space, as the outermost framework as well as the four frameworks of research methods proposed by Linda Groat \& David Wang [10], a strategy was developed referring to a research plan on mosque architecture and its context in the Sasak community. The strategy includes a series of research tactics, encompassing environmental observations and interviews conducted with the living sources who understand the history of the mosques related to the case. The identification of Baiturrahman mosque in Pendagi hamlet, Al Mujahidin Mosque in Ngorok hamlet, and Kopang Paer village center in Darussalam mosque as the case studies because of the complete historical background and information of the problem. Then, by generalizing the findings, as in On Case Methodology proposed by Rolf Johansson [11], that generalizations can be made from one case through analytical reasoning that combines deductive, inductive, and abductive processes. The study initially looks at the Sasak culture, which creates the Paer space concept and its implementation in the activities carried out at the mosque as studied in these stages:

a. Identifying community activities in the mosque as the center of the tiered Paer space, from the smallest Paer hamlet, Paer village, to Paer region. The research strategy was implemented in the case studies studying about seven mosques that became the center of the tiered Paer space. Historical backgrounds and complete information from a series of interviewees supported this study. The research tactic includes the participation in the activities carried out in the mosque during the five prayer times (Fajr, Dhuhr, Asr, Maghrib, and Isha), participation in recitation, connection or getting acquainted with the speaker of the chairman of the mosque management and several worshipers who 
live in the residents around the mosque. The activities are held at the mosque in the three levels of the Paer area to observe the patterns formed from the relationship between the mosque and the community at each level of the Paer space as well as to obtain historical stories of the mosque and its village establishment.

b. Conducting an interpretive analysis of the community activity pattern continuously strengthens the reciprocal relationship between the mosque and the residential environment. Furthermore, this analysis is made in order to generalize the identified pattern for its suitability throughout the Paer region.

c. From the meaning of the reciprocal relationship, reinterpretation is carried out with an approach from the wisdom aspect of the Paer space owned by the Sasak community. So, it can become an Islamic residential and environmental planning model concerning the physical and spiritual aspects.

The three stages of this research were observed in the villages. Several hamlets represented the general environmental conditions of the bale langgak, hamlets, villages, and the Paer area in Lombok.

\section{RESULTS}

The expression about the Paer space in the Sasak language is found and is stated: "...oleq paer bat tipaq paer timuq, oleq paer daye tipaq paer lauq, ndekne arak penglampan sak ngoneq, jari tepade sabar, tawakal sengaq semendak te Bedait akherat sak tetu ndek arak sedine ", which means "... from West Paer to East Paer, from North Paer to South Paer, there is no long journey so that we always be patient and tawaqal because it only takes a moment to reach the hereafter which has no edge"[12].

This expression explains the meaning of Paer space for the Sasak people that reflects the whole worldview and Islamic-based values believed by the people of Lombok about the existential temporality, in line with the concept of Islam everywhere. The Paer referred to in the above expression is the division of the Paer space orientation area on the island of Lombok as Paer Bat for the Western region, Paer Tengaq for the Central region, Paer Timuq for the Eastern region, Paer Lauq for the Southern region, Paer Daye for the Northern region, and Paer Beliq for the Mount Rinjani area.

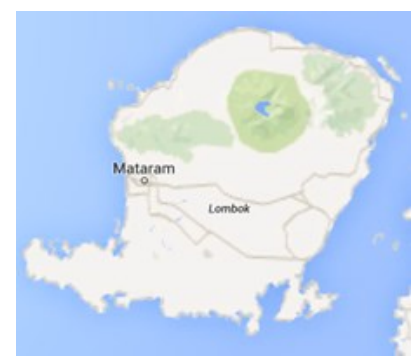

Figure 3. a map of Lombok island located between Bali in the west and Sumbawa in the east, from Google maps.
Even though Lombok is the Island of a Thousand Mosques [13], the data says it exceeds that.

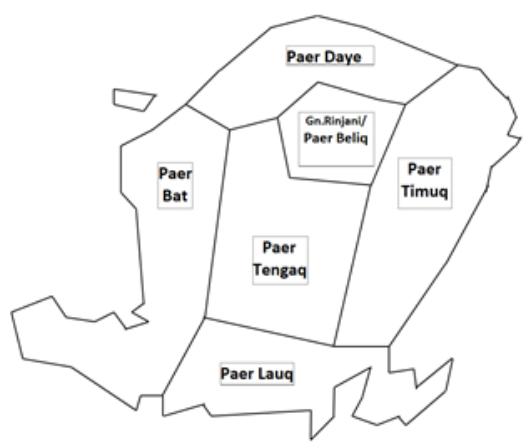

Figure 4. The division of the 6 Paer territories after the people of Lombok converted to Islam. Each level has a center of orientation as a continuation of the concept of space before Islamic Era. Each place has its natural object marker is called Ineun Tetaoq.

Based on the data recorded in 2017, taken from the Department of Population and Civil Registration of NTB from 536 villages throughout Lombok, there are 3,767 large mosques and 5,241 small mosques. So, in total, there are 9008 mosques. Therefore, this study places 9008 mosques in the Paer region, as explained in Table 1.

Table 1. Paer Territory and the number of mosques and villages in the island of Lombok.

\begin{tabular}{lccc}
\hline Paer Region & Village & $\begin{array}{c}\text { Great } \\
\text { Mosque }\end{array}$ & Small Mosque \\
\hline Paer Bat & 137 & 887 & 1014 \\
\hline Paer Daye & 33 & 291 & 234 \\
\hline Paer Tengaq & 103 & 1.019 & 1.651 \\
\hline Paer Timuq & 205 & 1.205 & 1718 \\
\hline Paer Lauq & 58 & 365 & 624 \\
\hline & 536 & 3.767 & 5.241 \\
\hline
\end{tabular}

Observations were made to describe the level of Paer space, hamlets, villages to the 5 Paer level areas with 9008 mosques written on the list above. Six mosques are involved in the case studies named the Baiturrahman mosque in Paer Pendagi hamlet, Darul Falah mosque in Paer Dusun Ngorok, Darussalam mosque in Paer Kopang village, Agung Praya mosque in Paer Tengaq area, Hubbul Wathon mosque in Paer Bat area, and Nurul Bilad mosque in Paer Lauq area. It was identified that the activities of praying together five times a day were continuously carried out in those six mosques.

The Paer Space for all Muslims worldwide is called Gumi Paer, with the center being the Al-Haram mosque in Mecca, Saudi Arabia. The goal of the entire Sasak community is the pilgrimage to the Al-Haram Mosque, as the form of worship with the highest value. However, the implementation of various cultural events always starts from the smallest environment in the Paer hamlet space, such as events related to baby birth ceremonies, baby haircuts (aqikah), weddings, or 
religious rituals carried out in paer bale langgak space, which is always associated with mosques.

\section{BAITURRAHMAN MOSQUE IN PAER DUSUN PENDAGI KOPANG VILLAGE}

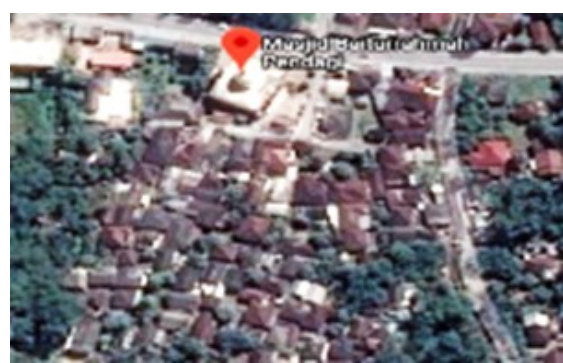

Figure 5 . Aerial photo of Dusun Pendagi, Kopang village, Central Lombok as downloaded from Google Maps on January 24, 2020, showing the position of the Baiturrahman mosque as the center of the Paer space of Pendagi hamlet surrounded by the clusters of Bale Langgak houses.

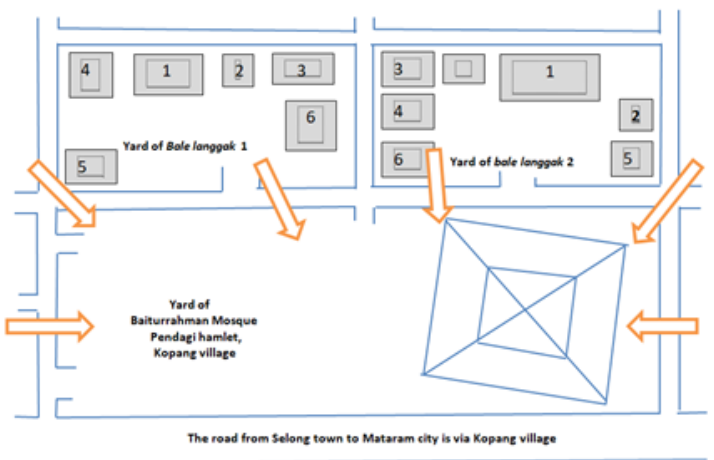

Figure 6. The schematic situation pattern of the Baiturrahman mosque is the orientation of the bale langgak cluster in the Pendagi hamlet.

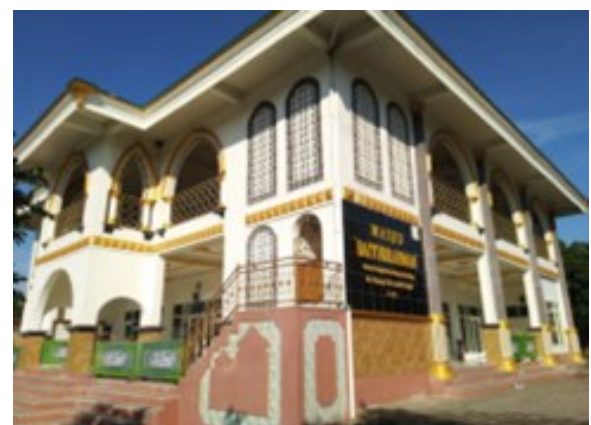

Figure 7. Baiturrahman Mosque in Pendagi hamlet, Kopang village, with a single domed roof model. (a)

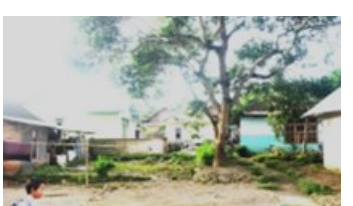

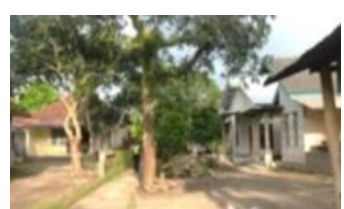

(b)
Figure 8 (a). Paer Bale Langgak 1, closest to the Pendagi hamlet mosque, Kopang village is inhabited by several closely related families called sorohan.

(b). Paer Bale Langgak 2, around the Pendagi hamlet mosque, Kopang village, is a big family related by kinship.

\section{DARUL FALAH MOSQUE IN PAER DUSUN NGOROK} KOPANG VILLAGE

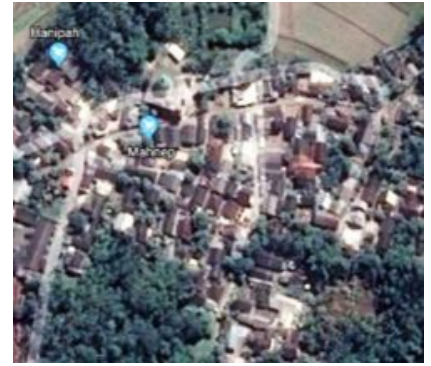

Figure 9. Aerial photo of Dusun Ngorok, Kopang village, Central Lombok as downloaded from Google Maps on January 24, 2020, showing the position of the Darul Falah mosque as the center of the Paer space Ngorok hamlet surrounded by clusters of Bale Langgak houses.

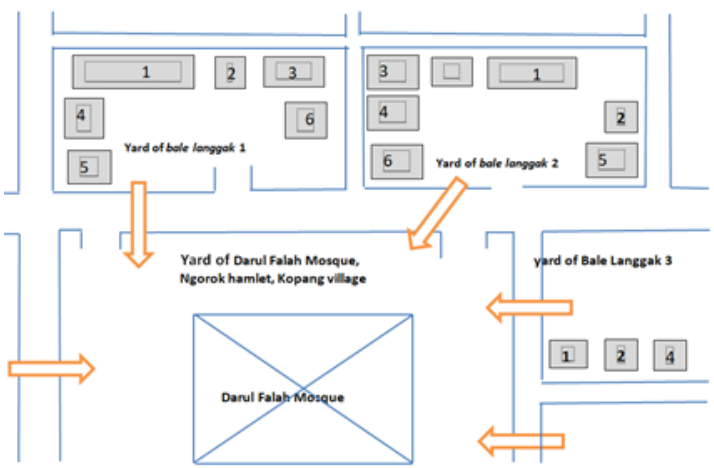

Figure 10. The schematic situation pattern of the Darul Falah mosque is the orientation of the bale langgak cluster in the Ngorok hamlet.

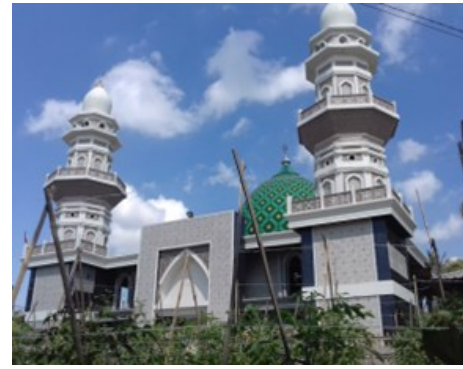

Figure 11. Darul Falah Mosque was recently renovated in early 2020 with an architectural design that uses a single dome and twin towers.

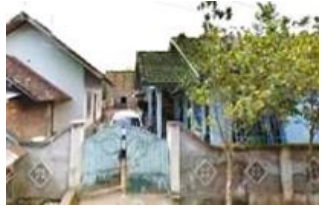

(a)

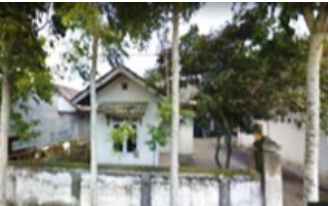

(b)
Figure 12 (a). Per Bale Langgak 1, closest to the Darul Falah mosque, the hamlet of Ngorok, Kopang village, is inhabited by several families closely related to sorohan.

(b). Another Paer Bale Langgak 2 around the village mosque Ngorok Kopang village is inhabited by one big family related by kinship.

240 | Journal of Islamic Architecture, 6(4) December 2021 
The relationship formed due to community activities in the Paer space of Ngorok and Pendagi hamlets is a permanent and temporary relationship. The pattern of permanent relationships in Paer space was formed because of the prayer activities of Paer Bale Langgak with Darul Falah Mosque and Baiturrahman Mosque. This is a permanent relationship and is consistent every day. All residents of Bale Langgak perform prayer activities and learn the Quran in the mosque so that each Bale Langgak cluster can be connected to the mosque and can form the strongest pattern of parlors in the Ngorok and Pendagi hamlets. The mosque functions as a performance zone to direct the activities of Bale Langgak residents in the Paer space, making it the center of the Paer space in the hamlet and village environment.

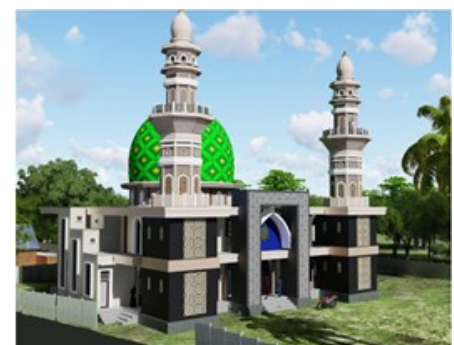

Figure 13. Bird's eye perspective plan of Darul Falah mosque, Ngorok hamlet, Kopang village

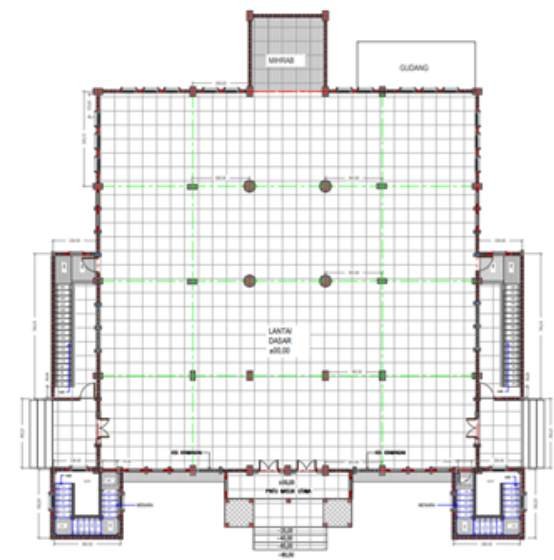

Figure 14. Ground floor plan of Darul Falah mosque in Ngorok hamlet, Kopang village

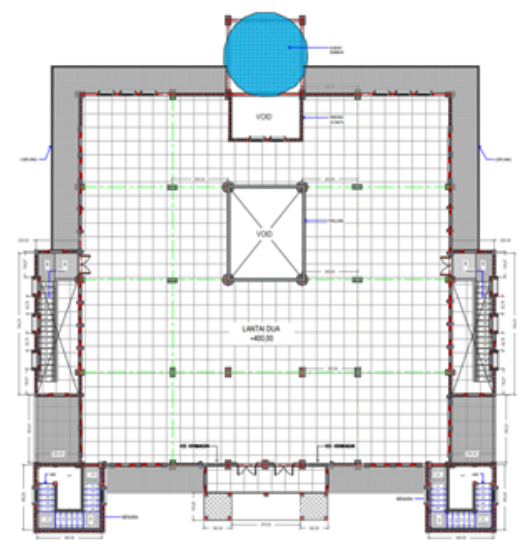

Figure 15. Second-floor plan of Darul Falah mosque, Ngorok hamlet, Kopang village

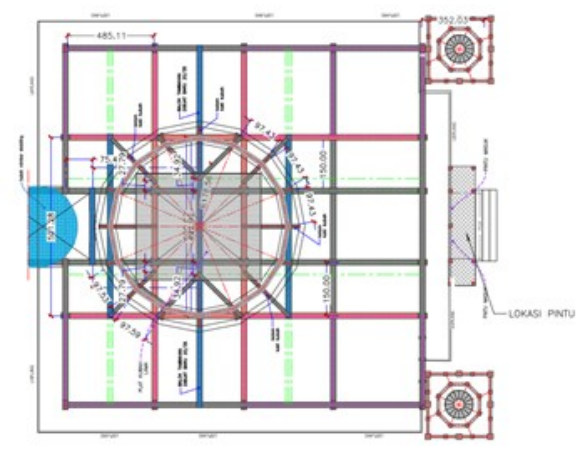

Figure 16. Floor plan of the roof of the Darul Falah mosque in Ngorok hamlet, Kopang village

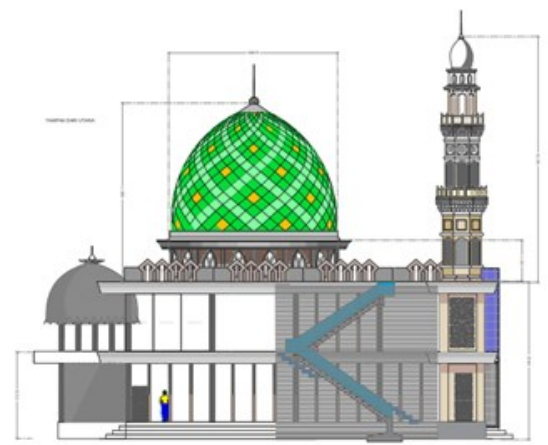

Figure 17. The image shows the minaret and section of the Darul Falah mosque in Ngorok hamlet, Kopang village

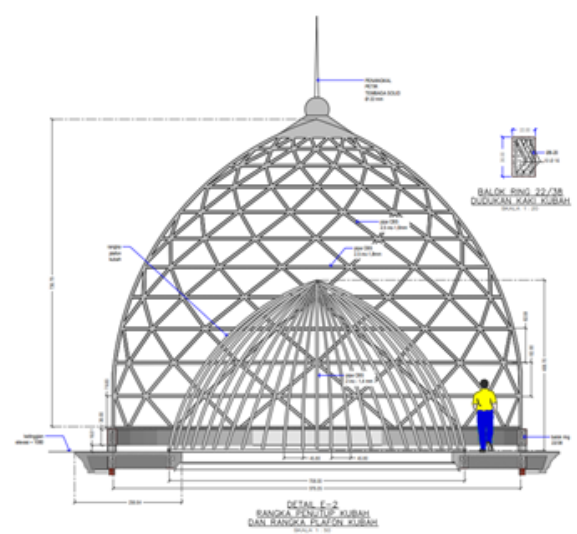

Figure 18. The structure of the dome frame and the ceiling frame under the dome of the Darul Falah mosque, Ngorok hamlet, Kopang village

The pattern of temporary relationships occurs due to various cultural activities and the commemoration of Islamic holidays. Important cultural events are related to the birth of a baby, circumcision, marriage, and death. Islamic holidays that are commonly commemorated in Lombok are the Birthday of the Prophet Muhammad, Eid Al-Fitr, and Walimatusysyafar or farewell from the community members who will carry out the pilgrimage to Mecca. These cultural activities create a temporary pattern in the Paer space.

The residents of the Bale Langgak cluster pray at the hamlet mosque five times, namely the Fajr prayer before sunrise, the midday/Dhuhr prayer at 
noon, Asr prayer in the afternoon, Maghrib prayer at sunset, and Isha prayer at night. During Ramadan, prayer activities will increase, and the number of visitors to the mosque will increase, making the relationship pattern in the Paer space stronger. Thus, the pattern of the relationship between the mosque and the houses of the Bale Langgak cluster residents becomes a powerful permanent relationship in every Paer space, which will continue as long as the hamlet exists.

\section{DARUSSALAM MOSQUE IN PAER KOPANG VILLAGE}

The Darussalam Mosque is the center of the Paer space in Kopang village, which is used for the five daily prayers by the residents of the closest bale langgak on weekdays so that the number of participants does not fill the entire large space. However, on Friday, the Darussalam mosque will be full of people coming from all hamlets in the Kopang village area to perform the worship. It became a gathering place for villagers from all over the hamlets during the time for Eid al-Fitr prayer, Eid al-Adha prayer, and the Prophet Muhammad's Birthday commemoration at the Kopang village level.

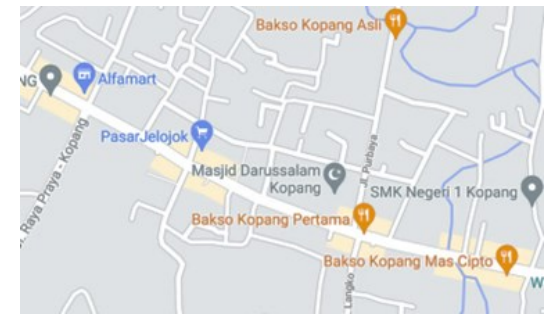

Figure 19. Google map of the position of the Darussalam mosque in Kopang village (downloaded on July 1, 2021).

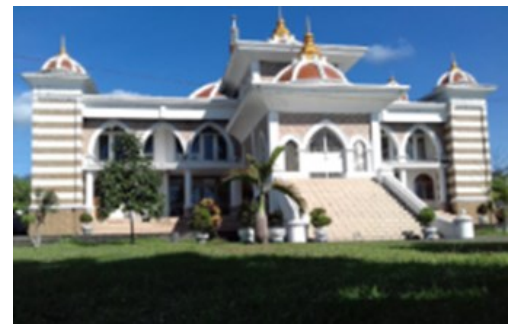

Figure 20. The front view of the Darussalam mosque in Kopang village with a roof dome in the shape of a "tebolak" or traditional food cover from Sasak culture.

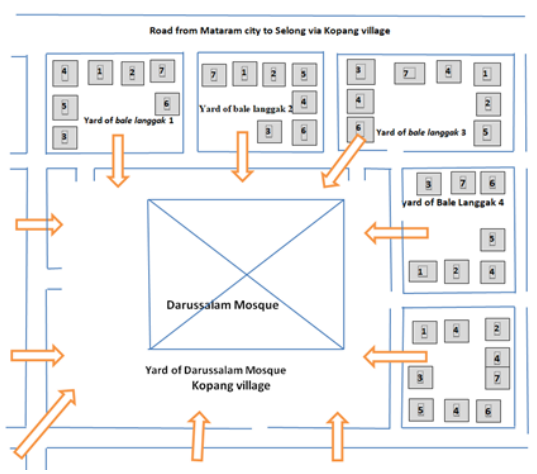

Figure 21. The schematic situation pattern of thDarussalam mosque is the orientation of the surrounding bale langgak cluster in the village of Kopang.

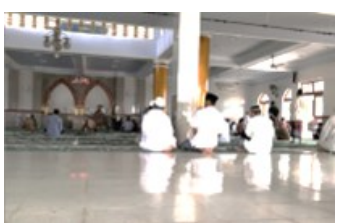

(a)

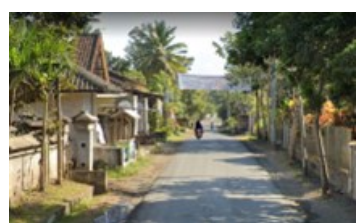

(b)
Figure 22 (a). Interior atmosphere of the Darussalam mosque in Kopang village ahead of the joint prayer service.

(b). The situation of the bale langgak around the Darussalam mosque in Kopang village.

\section{THE GREAT MOSQUE OF PRAYA IN THE PAER TENGAQ REGION}

It is the central mosque of the Paer Tengaq space, located in Praya city, Central Lombok district. The Great Mosque of Praya, founded in 1979, was previously only a small prayer room on an area of 4 hectares; then, it was renovated, was completed in 2000, and was a category of the Great Mosque. It's located on Jalan Sukarno Hatta Praya. The Great Mosque of Praya has a building area of 1,000 m2 with Waqf land status. This mosque has a modern architectural style with white patterned walls and a dark blue combination on the dome. The main building of the mosque consists of two floors and one ground floor. This mosque can accommodate 10,000 worshipers.

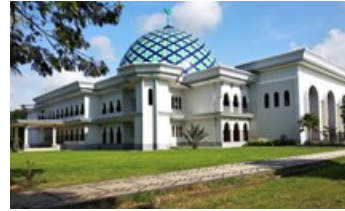

(a)

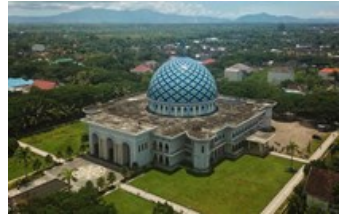

(b)
Figure 23 (a). The exterior view of The Great Mosque of Praya, the center of space for the Paer Tengaq area, was completed in the 2016 renovation. The architecture is a single dome roof shaped like tebolak (traditional Sasak food cover) without a minaret.

(b).The bird-eye view of The Great Mosque of Praya as the center in the Paer Tengaq area has a single dome in the middle of the axis of the building's symmetry and does not use a minaret.

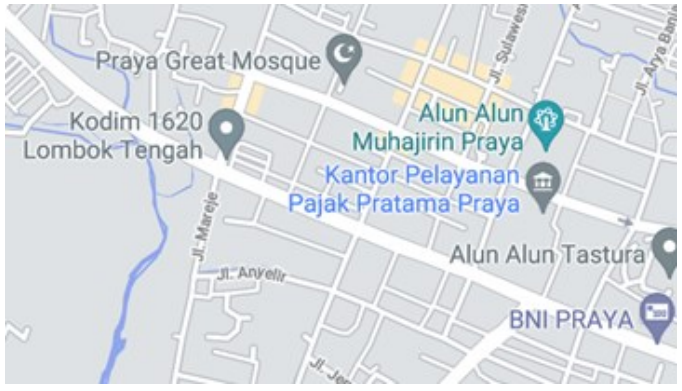

Figure 24. Google map showing the position of Praya city in Central Lombok Regency Lombok 


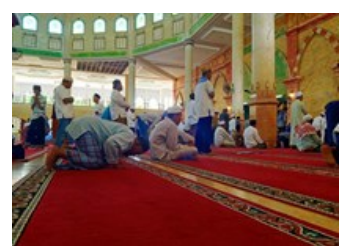

(a)

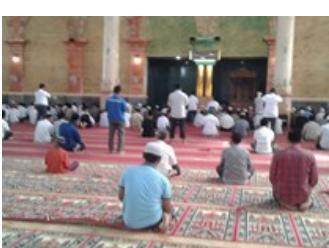

(b)
Figure $25(a)(b)$. The interior atmosphere before praying together at the Great Mosque of Praya.

\section{THE HUBBUL WATHON MOSQUE IN THE PAER BAT REGION}

The Hubbul Wathon Mosque in the Islamic Center area of Mataram city was completed in 2007 to meet the needs of a worship center and, at the same time, an orientation center in the Paer Bat area. Previously, there was an At-Taqwa Great Mosque in a nearby location just across the road. Still, it is old, and its capacity is insufficient because many mosques have been built in bigger and better villages. This Islamic center has been completing the landscape of Lombok Island as an island of thousand mosques, proofing the compatibility of Islam with modernity [14].

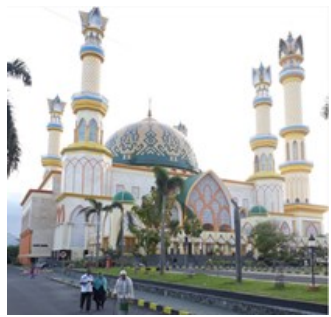

(a)

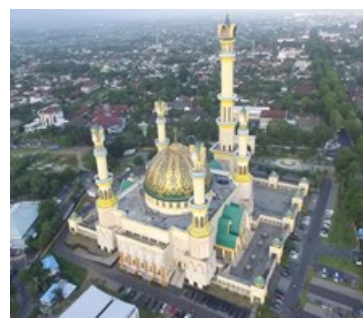

(b)
Figure 26 (a). An exterior view of the Hubbul Wathon mosque, the center of the Paer Bat area, was completed in 2007. The architecture is a single dome roof shaped like a tebolak (traditional Sasak food cover) surrounded by four towers as high as 99 meters and one tower as high as 117 meters.

(b). Bird-eye view of the Hubbul Wathon mosque as the center of the Paer Bat area, which has a single dome in the center of the axis of symmetry of the building and is surrounded by five minarets.

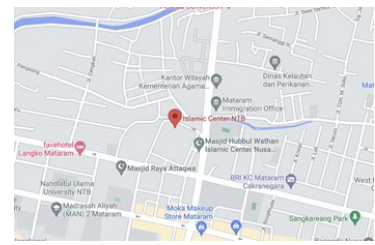

Figure 27. Google map showing the position of the Islamic Center of Mataram city in the Paer Bat area

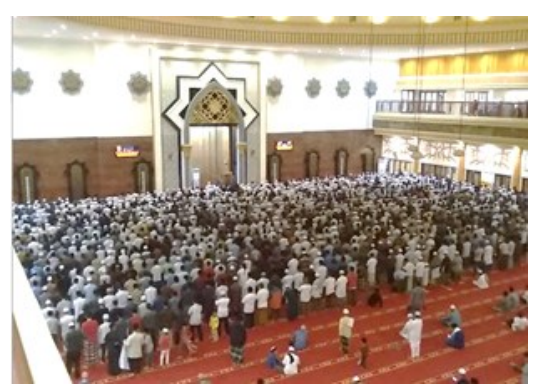

Figure 28. The interior atmosphere of the Hubbul Wathon mosque when the new prayer event begins.

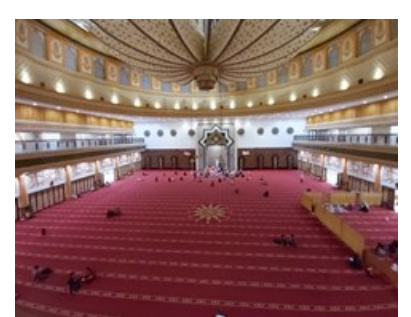

(a)

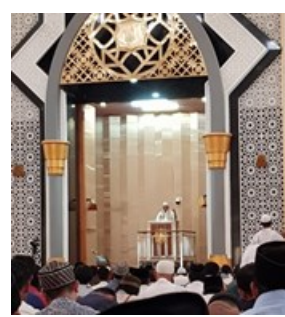

(b)
Figure 29 (a). The interior of the Hubbul Wathon mosque shows the shape of the ceiling under the dome, which is shaped like a tebolak (traditional Sasak food cover) upside down.

(b). The mihrab of the Hubbul Wathon mosque is the place for the imam and khatib who lead the behavior setting of all visitors in the mosque's interior who perform worship.

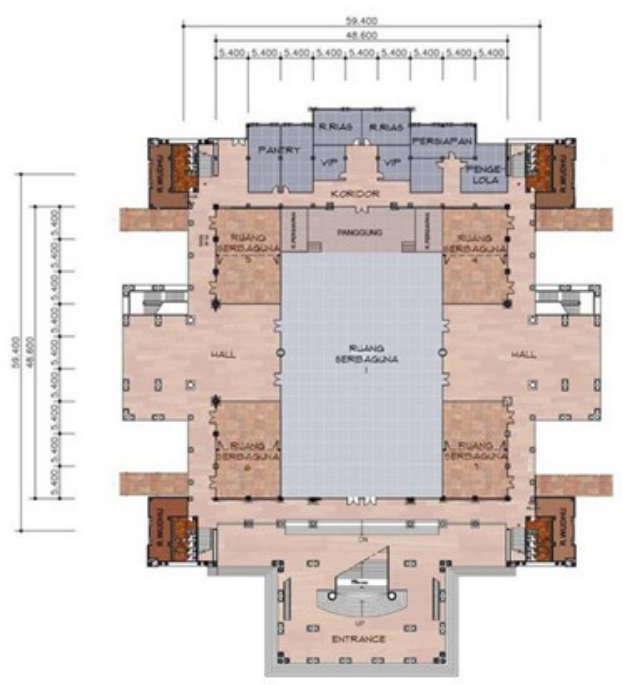

Figure 29. Ground floor plan of the Hubbul Wathon Mosque in Paer Bat Region

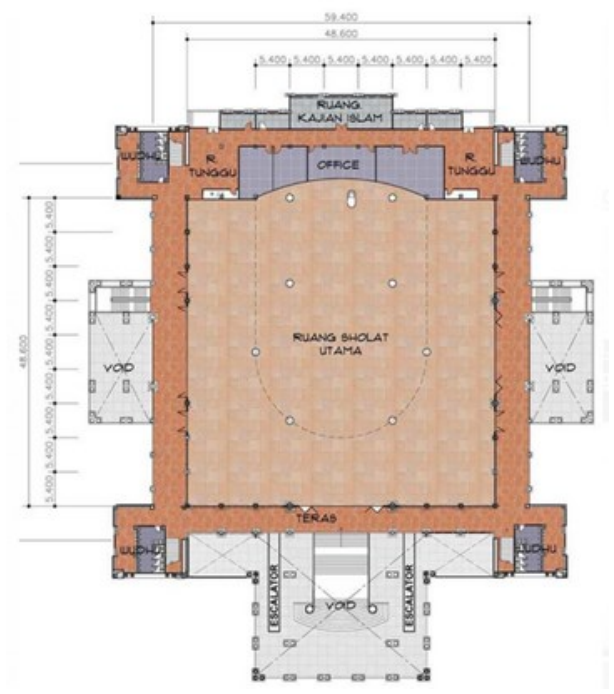

Figure 30. Second-floor plan of the Hubbul Wathon Mosque in Paer Bat Region 


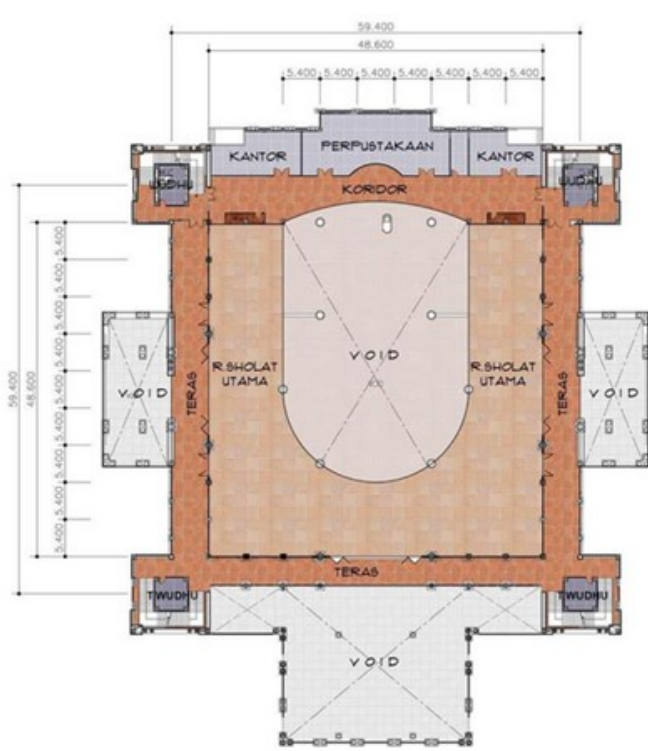

Figure 31. Mezzanine floor plan of the Hubbul Wathon Mosque in Paer Bat Region

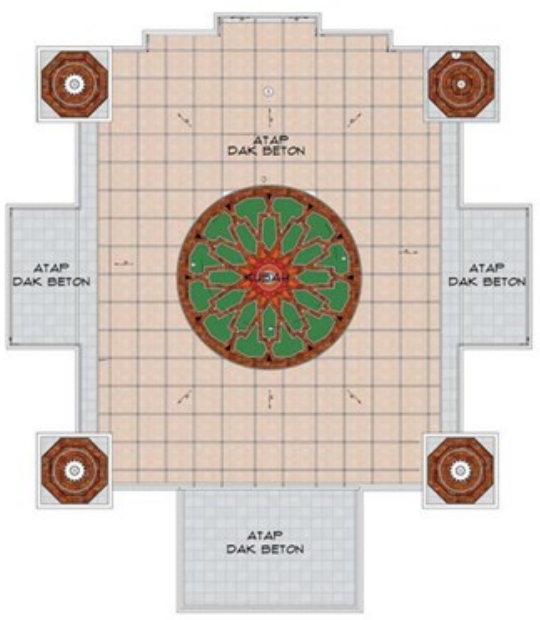

Figure 32. Roof plan of the Hubbul Wathon Mosque in Paer Bat Region

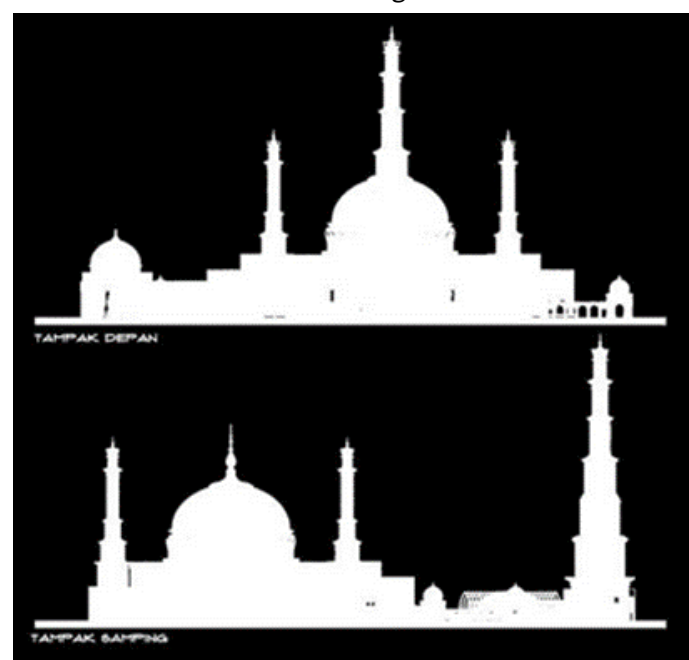

Figure 33. Front view and side view of the Hubbul Wathon mosque in Paer Bat Region

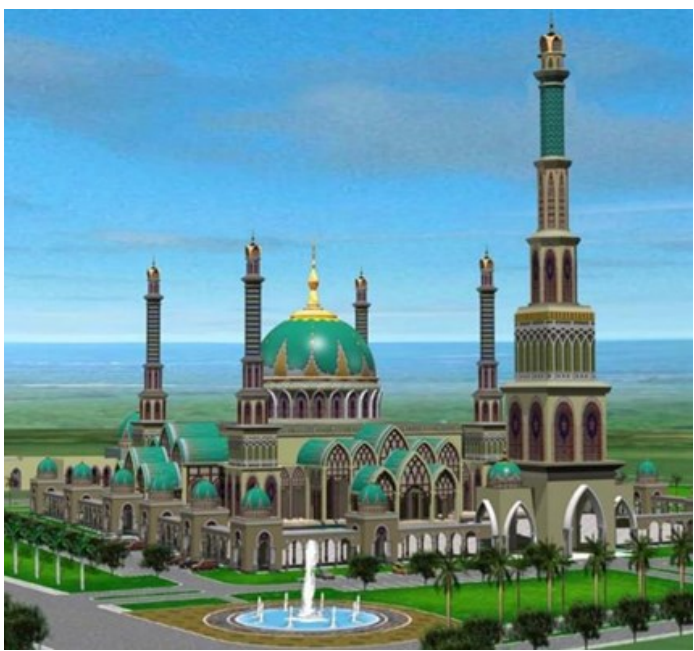

Figure 34. Bird-eye view of the Hubbul Wathon Mosque in Paer Bat Region.

\section{AL MUJAHIDIN MOSQUE SELONG IN THE PAER TIMUQ} REGION

It is a space functioning as an orientation center in Paer Timuq, located on Jalan Tuan Guru Haji Abdul Majid no 110 Sandubaya, Selong. The mosque building stands on an area of 1.2 hectares with a building area of 1540 square meters. The initial construction process of the Al-Mujahidin Grand Mosque began in 1957 to accommodate 5000 worshipers at once. In addition to the main dome covered in light green and dark green, the Al-Mujahidin Grand Mosque has four minarets attached to the building. The four towers rise up to 27 meters, flanking the main dome in the middle of the mosque's roof.

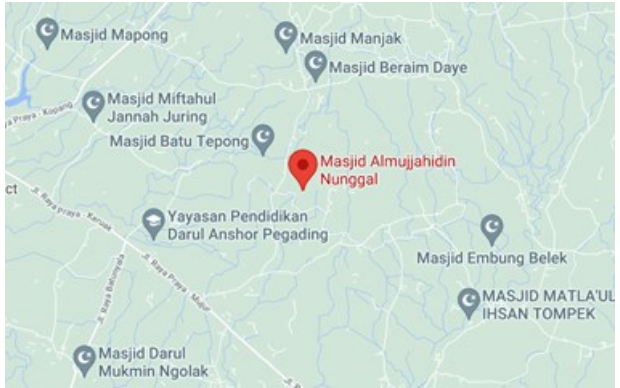

Figure 35. Map of the area in Selong, East Lombok, shows the position of Al Mujahidin mosque from Google maps, downloaded on 23 May 2021.

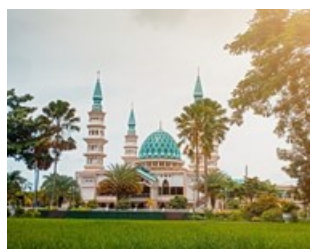

(a)

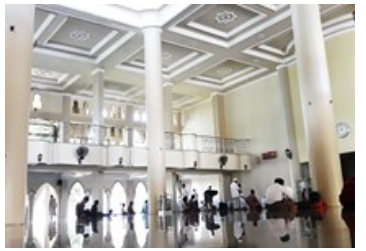

(b)
Figure 36 (a). Al Mujahidin Mosque is located in Selong, East Lombok, and is the center of spatial orientation for the Paer Timuq area. The roof is a single dome model of concrete and four towers that peak like green domes.

(b). The interior of the Al Mujahidin mosque is dominated by the ceiling pattern, while the interior does not refer to the guidelines. 


\section{NURUL BILAL MANDALIKA MOSQUE IN PAER LAUQ REGION}

Nurul Bilad Mosque, means the light of the nations, was intended to be built as a religious tourist spot around the Special Economic Zone of Kuta Mandalika Beach. This mosque stands on an area of 8 hectares with a huge yard. It was built for the first time before the surrounding five-star hotels were completed; it was also the case for other residential areas in Lombok, which started with the mosque to become an environmental orientation. However, because the built environment was still empty, the village mosque, functioning as a prayer space was still small. Yet, with a reasonably large yard, when there were many bale langgak, the people between the bale langgak developed the mosque, which was originally small, into a large building, and it was much better than their homes as the center of the Paer space of the hamlet.

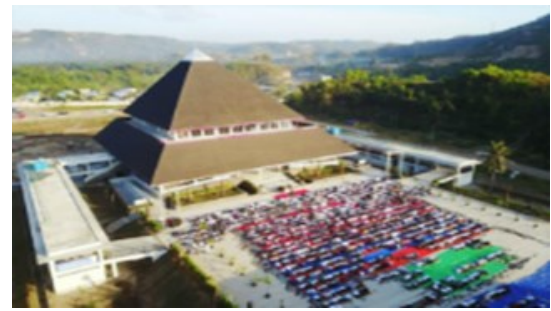

Figure 37. The architecture of the Nurul Bilad mosque with a roof shape that does not use a dome but a pyramid-like jagged roof, taking inspiration from the shape of the mosque in Bayan village in the Paer Daye area, which was first established in Lombok.

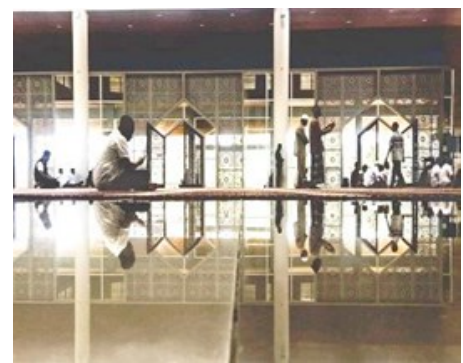

Figure 38. The interior of the Nurul Bilad mosque, which is also modern like the exterior architecture, uses a shiny floor and transparent glass walls decorated with geometric patterns using the sandblasting technique.

\section{MOSQUE ARCHITECTURE AND CULTURAL ACTIVITIES OF THE SASAK SOCIETY}

The mosque's architecture, which acts as the center of the Paer space multidimensionally, embodies the message of Islam; as the realization of the life goals of the people and the principles of God in space and time, it promotes the lifestyle produced by these philosophies and principles. The concept of Paer space orientation binds its citizens in a value system that is always connected to the mosque. The mosque is the most important building for Muslim communities everywhere; it is a gathering place for prayer and togetherness in social activities [15]. However, mosque is a worship place, and dominant values bind the community. Apart from its spiritual value, it also represents the Sasak culture.
The wedding ceremony also forms a temporary pattern of paer space based on the sequence of processes. Marriage in the Sasak community is commonly carried out with the merariq custom, contributing to a distinctive perspective on marriage. Marriage is carried out after the introduction of the man to the woman's house called a midang. If there is a match, then the wedding ceremony is planned according to the traditional merariq custom, where the man brings the woman to the hamlet head for customary protection. The next phase is the sejatiselabar event, where the men come along with the head of the hamlet asking the women to agree to carry out the marriage and negotiate the wedding fees set by the pembayun or the officer for the amount of ajikrama. In the procession, three laws were applied as a guide; religious law, customary law, and state law, which are all applied in an integrated manner [16]

It is then followed by the sorong-serah event, namely the visit of the man to the woman's family to hand over the ajikrama accompanied by relatives and live music called gendang beleq. Finally, the climax is the ijab-kabul ceremony, an Islamic endorsement led by the head of the Office of Religious Affairs which is carried out at the mosque. The end of the event is marked with bejango, where the bride and groom say goodbye to the bride's family to settle in the resident of the groom's family [17]. Thus, wedding rituals form a paer space pattern, where the core of the event is in the mosque and the house in the bale langgak of each bride and groom is another location when the ritual sequence occurs.

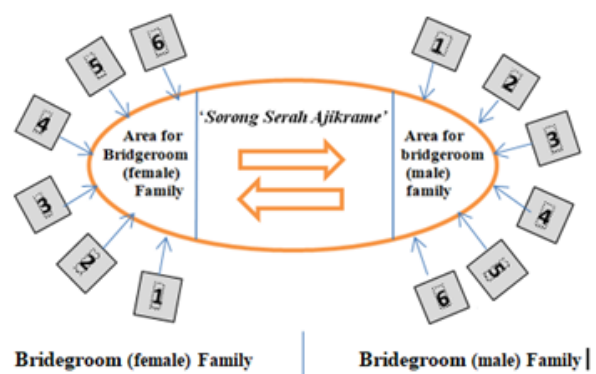

Figure 39. The pattern of paer space is based on the "Sorong Serah Ajikrame" activity in Marriage Ritual. The elements of the party Bride: 1. Banjar representative 2. Pembayun 3. Belian 4. Keliang (hamlet head) 5. Kyai 6. Relatives. Elements of the Groom: 1. Relatives 2. Friends 3. Kyai 4. Keliang (hamletNhead) 5. Belian 6. Banjar representative 7. Pembayun

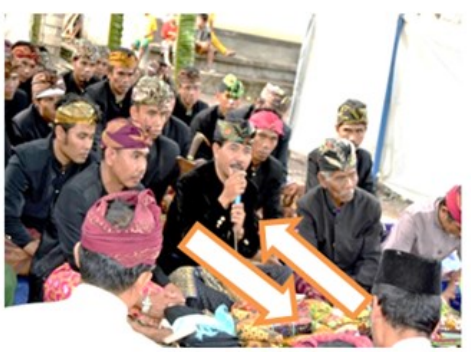

Figure 40. Dialogue conducted by two Pembayun representing each side of the bride's family in the ceremony of handing over the ajikrame or other costs and needs of the wedding. 
The temporary pattern of Paer space in the hamlet was also formed due to the Islamic commemoration of the Prophet Muhammad's birthday. The celebration of the Prophet's Birthday was always carried out by the people of Lombok by holding a dulang tradition or eating together after listening to the words of wisdom uttered by the ulama to increase the sense of togetherness and sharing [18]. At this event, there was a temporary relationship in the paer space between the bale langgak residents of the vicinity and the mosque's orientation.

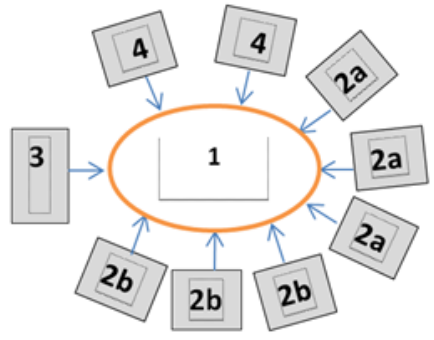

Figure 41. Paer space pattern diagram based on the Prophet's Birthday Commemoration Activities in the residential hamlets of the Sasak community. Description: 1. Mosque. 2a. Female community 2b. Male community 3. Master Teacher 4 . Community Leader.

In psycho-social interactions, the paer space is manifested in an atmosphere that directs behavior and is at the same time influenced by human behavior in it. The atmosphere formed in the paer space acts as a behavior set that provides stimuli to the behavior of the community members, and vice versa, the activities or behavior of the residents will affect the formation of the paer space atmosphere. Behavioral control or behavior settings is caused by influential elements such as the sound of the call to prayer from the mosque's minaret, which calls the residents of the surrounding community to pray. The imam or preacher in the mosque leads worship activities. In a behavioral control area, the most influential place is the performance zone; in the mosque, it is the mihrab section [19].

On a hamlet paer space scale or village paer space, the performance zone is the area where the mosque's architecture is located. The mosque's existence, with each house of the residents who come and go five times a day after praying together in the mosque, creates a behavioral control with a strong pattern. Therefore, the performance zone in the behavior setting in the village paer space is the mosque.

Another activity for villagers that forms a nonpermanent pattern in the paer space is Walimatusysyafar, a banquet to say goodbye to the residents who will perform the Hajj, pilgrimage to Mecca. This event is held at the mosque if several people depart, and al the heads of families from the villagers are invited. This event is also called the rowah tradition in the Sasak community. Socially, it is a medium of friendship between friends, relatives, and neighbors to forgive and bid farewell to each other with prospective pilgrims [20].

The mosque's architecture in Paer space is intended to create a space atmosphere that meets the needs of Muslims from prayer services to cultural activities and a gathering place for celebrating holidays and social activities. The mosque depicts a Muslim establishment that acts as a symbol and encouragement of Islamic life. It represents Muslims' identity in addition to the main purpose of worship and social aspects [21]. The mosque's architecture in Paer space shows its function with all its dimensions: corporeal, cerebral, and spiritual. The role of form is also significant, but it is only a supporting and enhancing element for function [17].

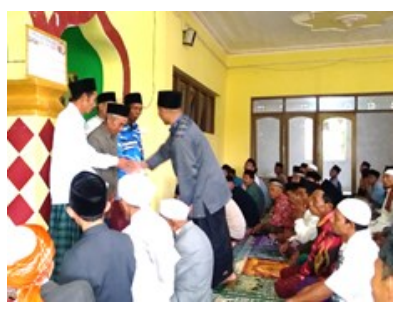

(a)

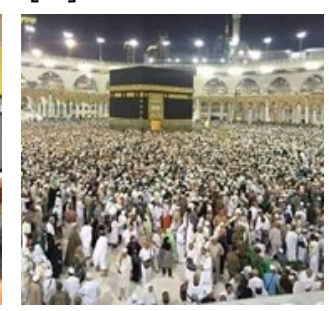

(b)
Figure 42 (a). The Walimatusysyafar event to bid farewell to the hamlet residents who will perform the Haji, a pilgrimage to Mecca, is carried out at the mosque if there is more than one prospective Hajj congregation.

(b). Al-Haram Mosque in Mecca, in the concept of the Paer space, is the center of Gumi Paer or Paer throughout the world, which is the orientation and aspiration of every people of Sasak hamlet to visit and pray in it.

The concept of Paer space as a place of the existential existence before going to an eternal life in the hereafter makes the mosque architecture an orientation as well as a center for activities while spending one's remaining time in life. This is in line with the linguistic understanding of the mosque as a 'gathering place' to fill in the waiting period in Paer space. The waiting period, which is undoubtedly short compared to the time after the eternal life, will certainly be filled with appropriate activities for that journey into the future. The mosque becomes a performance zone from the people's behavior who gather in it, in a fixed and sustainable time pattern. This behavior illustrates, intentionality directed at the goal of the hereafter, and more concerns with things that are good for the waiting period; it also considers other things unimportant in this waiting period. Sasak people periodically gather at the center of the paer space, the mosque, to maintain a permanent connection with a future that is eternal and certain to come. Therefore, no matter how small, every residential environment always strives to be close to the mosque. Every hamlet has a mosque, and the number of mosque architectures throughout Lombok reaches 9008 artifacts.

The meaning of the mosque designation as Baitullah is a building in the existential world, a place to worship God together. Therefore, any activity is performed based on the context of "Because in Islam, 
worshipping Allah can only be performed during the waiting period in Paer space." After passing the existential period, there is no longer activity as worshipping God. Therefore, worshipping Allah lasts only during one's existence in this world, and eternal time in the hereafter is merely a consequence of the choice of this way of life. Thus, the mosque as the Paer space center and the embodiment of the "house of God" is needed by the Sasak community more than their place to live.

Carrying out cultural activities, for the Sasak people, must also be in line with the goal of the waiting period in Paer space that is achieving happiness in the eternal life of the hereafter. Thus, culturally commemorated events such as the birth of a baby, marriage, death, Eid al-Fitr, Eid al-Adha, and the Birthday of the Prophet Muhammad will always be associated with the Paer space central mosque. Because of that, the mosque has a very strategic position and has a big influence on the Sasak community, so there are several Bale Langgak neighborhoods with more than 40 residents. The concept of Paer space centered in the mosque is to embody the Islamic concept embraced by the Sasak people for existential life, which merely awaits the eternal life in the hereafter. In line with the comparison about this existential world in Islam with eternal life in the hereafter is like a drop of water in the middle of a vast ocean; it is not comparable. Therefore, to define the development for the Sasak Muslim community means to realize ease and flexibility for the achievement in existential life and as far as possible to fulfill the criteria for an eternal afterlife.

\section{DISCUSSION}

According to the NTB Population and Civil Registry Office, mosques throughout Lombok have been identified as 9008 mosques, 3767 large mosques as village paer space centers, and 5241 small mosques as paer space centers in hamlets. There are so many mosque artifacts in Lombok although Islam came to this place later than to other areas in the archipelago. This is because the mosque does not only function to meet the needs of places of worship but also as a center for Paer space at the hamlet, village, and regional levels. The need for mosque space for prayer is excessive. The implementation of Friday prayers in several hamlets is scheduled only at village mosques. The minimum number of participants for Friday prayers must be exceeding 40 people to meet the requirements.

The concept of Paer space has the levels according to its scope, paer dasan for the hamlet, which consists of several Bale Langgak clusters, paer dese for the scope of several hamlets within the village area, and city paer for the scope of a city. There are also pairs based on the cardinal directions, namely Daye (North), Lauq (South), Bat (West), and Timuq (East). Finally, the entire Paer space is considered to be centered on one central point on earth, namely Paer Gumi that is located in the holy city of Mecca, which is the dream of every Sasak people to visit for Hajj or Umrah.

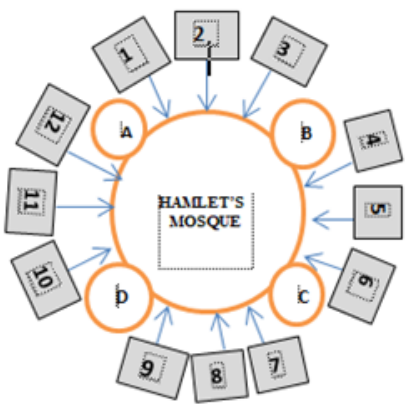

Figure 43. Spatial Structure of Paer in traditional hamlets frequented by tourists, formed between Bale Langgak and the mosque because worship rituals and cultural activities are the strongest spatial structures. 1, 2, 3, 4, 5, 6, 7. and so on are bale langgak cluster, or family houses of hamlet residents who are also bound to the mosque, A, B, C, and D are stalls and facilities used by hamlet group craftsmen for buying and selling activities.

The level of paer space is a place that covers the lives of the Sasak people, starting from the Bale Langgak cluster in the hamlet or Banjar attachments in the village to the urban environment. All levels of Paer have a mosque as their center, which is built by the community financially, energy, or other thoughts and participation. Every mosque construction is considered as an implementation of the message of Islamic spirituality to pave the way for the participatory establishment of ritual and institutional prayer activities with infrastructure that will have an impact on the goodness in the eternal hereafter. The process and scope of citizen participation in the mosque's construction can be seen from planning to architectural completion; form, space, choice of materials, and details are also managed openly. The method of building and financing also varies for each mosque, but all of them are based on mutual agreement and deliberation to promote the broadest possible participation.

The existence of levels in the concept of Paer space covers all existential spaces, from the smallest in the Bale Langgak cluster to Gumi Paer, which refers to the holy city of Mecca as the center of the earth. So, the scope of this concept is universal; it is not limited to the island of Lombok only. Furthermore, substantive meaning can be found in Paer's concept of the life of all humans, which inevitably ends in death so that it becomes a moment of waiting that must be used as well as possible to lead to eternal life. Thus, the orientation of space and behavior in the waiting period must be intentional towards eternal life in the hereafter. The intentionality of this behavior is identified from the consistency of maintaining attendance at the mosque to carry out worship rituals, always reading and studying, and trying to implement the Quran and Hadith as the behavioral guidelines by obeying the things that are ordered and avoiding what is prohibited. Of course, many things can be identified 
as intentional behavior towards eternal life in the hereafter.

Intentional behavior towards the hereafter is habituated through an atmosphere of Paer space at every level of the Muslim community in rural and urban areas by using mosque architecture as a performance zone. The process is periodically and continuously intervened with intersubjectivity stimulus from the mosque's presence as the center of the Paer space. It is also stimulated at each initial schedule of prayer times through the prayer call (Azan) through the mosque tower. People who hear Azan's voice respond to their respective personality and subjectivity systems by involving systems of perception, cognition, and motivation, which are influenced by the background of their faith experience. This response forms the behavior of visiting the mosque and performing prayers and other worship. The worship process performed by the community in the mosque will then have the opposite effect on the atmosphere of the Paer space. Thus, it creates a reciprocal stimulus. Therefore, the community feels the stimulus of the mosque's space atmosphere, which is very different from performing worship at home.

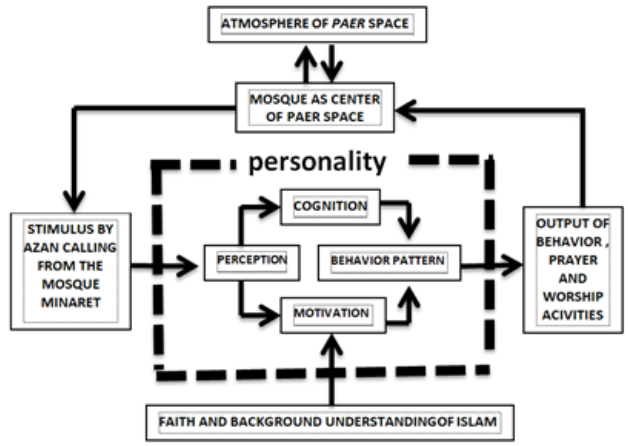

Figure 44. The scheme of the Paer atmosphere process with the mosque as its center provides stimulus to the personalities of each community member in their environment to shape individual behavior within the mosque, and vice versa. Thus, the behavior collectively influences the atmosphere of the Paer space.

Paer space atmosphere will be perceived as a vague situation but has an impact on the attitudes and behavior of the people. Each situation will move and change with the passage of time in the Paer space, which will not be felt clearly by the individuals in it. This continues periodically and is prolonged so that every movement of the displacement can be felt faintly. At a certain time, on Friday, you will feel a different Paer space atmosphere because of the Friday prayer activities conducted in the mosque. In Ramadan, it will be more lively for a whole month because the activities take place every day from the morning prayer until the time of the midnight prayer. The atmosphere of Paer space during the month of Ramadan in every hamlet, village, and city in Lombok will be felt by every community as a distinctive atmosphere that is different from other months because it is filled with worship events at the mosque. This is an event of mutual influence that is most strongly felt reciprocally between the behavior of each community and the mosque in Paer space.

The Paer space concept model is recommended, with the mosque architecture being the center of the environment integrated with educational facilities and a place for trades for necessities and others. Many mosques become the center of the Bale Langgak cluster and are integrated with madrasas. For example, some mosques hold Madrasah Diniyah, which teaches the materials of elementary school level combined with Islamic religious knowledge. Some others hold Madrasah Tsanawiyah at the junior high school level combined with Islamic religious knowledge. However, it is also recommended that village mosque institutions also seek to store necessities for the community. This opportunity is not filled by modern retail networks as has happened in several places. The problem is that the brand design of modern retail is very conspicuous. Its position is in front of the village entrance gate, so the village character, a collection of hamlets with the Bale Langgak cluster, is covered by the retail brand's bright lights.

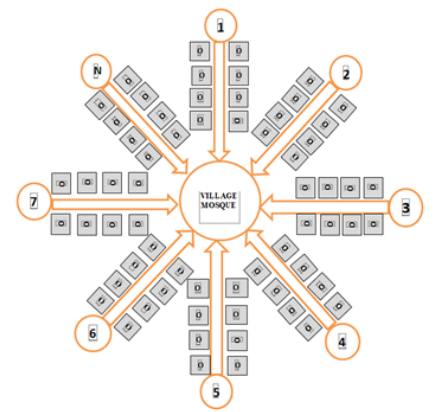

Figure 45. The spatial pattern of villages with the center of mosque orientation normally only functions as ritual worship.

This pattern exists in the majority of villages in Lombok. Explanation: 1, 2, 3, 4, 5, 6, 7 are the number of hamlets in the village area up to the number $\mathrm{N}$, o is each Bale Langgak cluster that gathers in each hamlet with the direction of the village mosque.

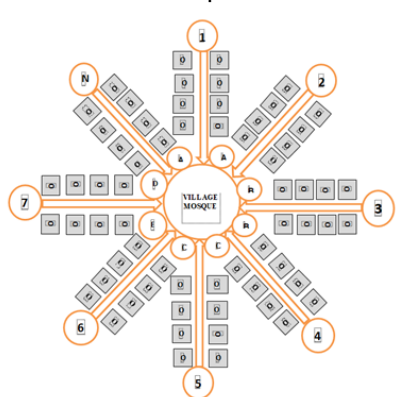

Figure 58: The recommended village space pattern with a mosque orientation center surrounded by Islamic-based educational facilities, Sharia cooperative economic activity facilities, and Village Community Hall. Explanation as follows: $1,2,3,4,5,6,7$ are the number of hamlets in the village area up to the number $\mathrm{N}$, o are each Bale Langgak cluster that assembles in each hamlet by referring to the village mosque, A. is madrasa Tsanawiyah at junior high school level, B. is madrasa Aliyah at senior high school level, C. Kindergarten, D. Sharia cooperative, E. Banjar village (village community hall). 


\section{CONCLUSION}

The Paer space center is a mosque architecture indicated as a joint place to carry out religious and cultural rituals to spend their remaining time while waiting for the afterlife to come. Still, in some traditional hamlets that are often visited by tourist, souvenir sales will also be included. Thus, the Paer space center does not only function as a place for ritual worship but also for developing social worship and muamalah transactions. So, the space level in the hamlet, village, and city is recommended to become a model for residential space patterns and activities for Islamic communities. The role of this model is an extension of the Islamic Center's meaning and function at all community environment levels in the appropriate facility scale. The strength of Paer's space model is its ability to build a spatial atmosphere that directs individuals in their community to behave and carry out activities that are intentional for an eternal life in the hereafter through activities with the center in the mosque. In Paer space, these activities and behaviors are carried out every day in a fixed time pattern in a sustainable manner that mutually influences the atmosphere of the space and its community.

The concept of Paer space indicates Islamic messages whose identification is strengthened by the center of the environment in mosque architecture. The message is a realization of the teachings of the Quran to always place existential life only as a temporary waiting and not a goal because the real goal is an eternal afterlife. Paer space facilitates the activities and behavior of Muslims to live a concise existential life in Islam to achieve the happiness of life in the eternal hereafter. The Paer space concept provides guidance on the purpose of life, which is realized by the center of space orientation by mosque architecture functioning as the places of worship rituals and cultural activities in the scope of multi-storey spaces from Paer Bale Langgak, the smallest in the village, to Paer Gumi which includes universal space. The center of Paer's space also guides the lifestyle generated by the philosophy and principles of that purpose.

\section{ACKNOWLEDGMENT}

This manuscript is written through a research funded by the Bandung National Institute of Technology, Institute for Research and Community Service (LPPM) through contract number: 298/8.05/ LP2M-Itenas/IV/2020.

\section{REFERENCES}

[1] T. Hidjaz, N. Soewarno, D. Fitriany, "The Symbolic Meaning of Mosque Architecture as Adaptation to the Residential Environment, in the Social, Eco nomic and Cultural Contexts in Lombok", International Journal of Architecture, Arts and Applications, vol. 5, no. 3, pp. 64-81, 2019, doi: 10.11648/j.ijaaa.20190503.11
[2] T. Hidjaz, "Arsitektur Mesjid Sebagai Adaptasi dan Orientasi Ruang dalam Budaya Sasak, Studi Kasus Desa Kopang Lombok Tengah", Zonasi Journal of Architecture, vol. 1, no. 1, pp. 1 -15, Juni 2018, DOI: https://doi.org/10.17509/ jaz.v111.11737

[3] A. Fathurrahman, Gumi Paer's Philosophy, NTB: Mataram State Museum, 2017

[4] Ashadi, "Correlation Between the Mosque and Traditional House Architecture in Kudus, Indonesia", International Journal of Built Environment and Scientific Research, Vol. 1, No. 01, pp. 17-26, 2017, DOI:https://doi.org/10.24853/ ijbesr.1.01.17-26

[5] Data of the NTB Province Community Empowerment, NTB: Population and Civil Registry Service Empowerment Office, 2017

[6] E. N. E. A. Mohamed, "Islamic Architectural Character Between legitimacy and Disparity", Journal of Islamic Architecture, Vol. 3, Issue 1, pp. 25-38, June 2014, DOI: https:// doi.org/10.18860/jia.v3i1.2537

[7] B. Stringer, "Architecture and Culture: A Villages and Globalization Issue", Taylor \& Francis, International Journal of Architecture and Culture, vol. 5, no. 1, pp. 1-4, May 2017, doi: 10.1080/20507 828.2017.1299434

[8] H. Khan, "Because We Can: Globalization and Technology Enabling Iconic Architectural Excesses", International Journal of Islamic Architecture, Vol. 7, No. 1, pp. 5-26, March 2018, DOI: https://doi.org/10.1386/ijia.7.1.5_2

[9] O. S. Asfour, "Bridging the Gap Between the Past and the Present: a Reconsideration of Mosque Architectural Elements", Journal of Islamic Architecture, vol. 4, no. 2, pp. 77-85, 2016, DOI: 10.18860/jia.v4i2.3559.

[10] L. N. Groat and D. Wang, Architectural Research Methods, New Jersey: John Wiley \& Sons, Inc., 2013

[11] R. Johansson, "On Case Study Methodology", Open House International, vol. 32, issue 3, pp. 48 -54, September 2007, DOI: 10.1108/OHI-03-2007Bo006

[12] T. Hidjaz, Lombok, Negeri Beribu Mesjid, Bandung: Penerbit Jurusan Desain Interior Institut Teknologi Nasional Bandung, April 2018

[13] Suprapto, "Penguatan Kearifan Lokal untuk Resolusi Konflik dan Upaya Bina Damai di Pulau Seribu Masjid", Jurnal Indo-Islamika, Vol. 1, No. 
1, pp. 21-40, 2011, DOI: https://doi.org/10.15408/ idi.v111.1484

[14] D. Wahyudin, "Mosque and Civilization: Setting Islamic Center of Nusa Tenggara Barat as Center of Civilization", Nalar: Jurnal Peradaban dan Pemikiran Islam, Vol. 4, No. 1, pp. 29-42, 2020, DOI: https://doi.org/10.23971/ njppi.v4i1.1921

[15] M. P. Adithia,"The Tradition of "Merariq" in Sasak Ethnic Group of Lombok Island". Indonesian Journal of Social Sciences, Vol. 2,No.1, pp. 1-20, 2010.

[16] W. Lukman, "Existence of Marriage in the Sasak Tribe in Lombok (Merariq) Within the Estuary of Legal Pluralism", Jurnal IUS Kajian Hukum dan Keadilan, Vol. 2, No. 3, 2014, DOI: http:// dx.doi.org/10.12345/ius.v2i6.179

[17] A. Subagio, "Sambut Maulid Nabi, Warga Lombok Pupuk Kekompakan Lewat Tradisi Dulangan," Ini Baru Indonesia, Nov. 19, 2018. https://www.inibaru.id/tradisinesia/masyarakat- lombok-sambut-maulid-nabi-dengankekompakan-dalam-tradisi-dulangan (accessed Nov. 01, 2020).

[18] T. Hidjaz, Interaksi Psiko-Sosial di Ruang Interior, Bandung: Jurusan Desain Interior Itenas, April 2011

[19] Fahrurrozi, “Lombok Sasak Community Hajj Ritual: A Sociological-Anthropological Domain", Journal of Islamic and Cultural Studies, Vol. 13, No. 2, pp. 61-78, Juli - Desember 2015, DOI: 10.2409o/ibda.v13i2.661

[20] S. Omer, "The Concepts of God, Man, and The Environment in Islam: Implications for Islamic Architecture", Journal of Islamic Architecture, vol. 2, no. 1, 2012, DOI: $\quad$ 10.1886o/jia.v2i1.1778

[21] H. J. S. Haraty, N. Utaberta, 2020 "Contemporary Trends of Research and Writing on Mosques Design: Analysis of The Most Recent Publications", International Journal of Engineering and Technology, vol. 9, No. 1, pp. 528-532, 2020, 